\title{
The Use of Non-reef Habitats by Brazilian Reef Fish Species: Considerations for the Design of Marine Protected Areas
}

\author{
Daniele Alves Vila-Nova ${ }^{1,2}$, Mariana Gomes Bender ${ }^{1,2}$, Alfredo Carvalho-Filho ${ }^{4}$, \\ Carlos Eduardo Leite Ferreira ${ }^{5}$ \& Sergio Ricardo Floeter ${ }^{1,2,3, *}$
}

\author{
${ }^{1}$ Programa de Pós-Graduação em Ecologia e Conservação, Setor de Ciências Biológicas, \\ Universidade Federal do Paraná - UFPR, Curitiba, PR, Brazil \\ ${ }^{2}$ Laboratório de Biogeografia e Macroecologia Marinha, Universidade Federal Santa Catarina - UFSC, Florianópolis, SC, Brazil \\ ${ }^{3}$ Programa de Pós-Graduação em Ecologia, Universidade Federal de Santa Catarina - UFSC, Florianópolis, SC, Brazil \\ ${ }^{4}$ Fish Bizz Ltda., São Paulo, SP, Brazil \\ ${ }^{5}$ Laboratório de Ecologia e Conservação em Ambientes Recifais, Departamento de Biologia Marinha, \\ Universidade Federal Fluminense - UFF, Niterói, RJ, Brazil
}

\begin{abstract}
Many reef fish use non-reef habitats (e.g. mangroves, estuaries, and seagrass/algae beds) during their life cycle. In this study we determined how many, and which percentage of Brazilian reef fish species that make use of non-reef habitats are considered threatened (i.e. red-listed) and/or targeted by fisheries. We compiled data for 559 reef fish species, which were sorted by habitat use, threat and/or target status. Three-quarters $(N=27)$ of all threatened species, and $87 \%(N=207)$ of targeted species use non-reef habitats. São Paulo and the 'Hump of Brazil' (PB-AL) had the highest number of targeted species using non-reef habitats. Estuaries presented the highest number of both threatened and targeted species. Additionally, this is the habitat that has the lowest protection on the Brazilian coast. We suggest that conservation strategies should include the protection of ecological corridors among reefs and other habitats for an effective management of Brazilian reef fishes.
\end{abstract}

Key words: Conservation, EBM, Habitat-use, Targeted Species, Threatened Species.

\section{Introduction}

It is broadly known that reef fish may use non-reef habitats (e.g. mangroves or seagrass/algae beds), during their life cycle (Mumby 2006). The proximity of mangroves and seagrass/algae beds with reefs increases the fish abundance and richness in these areas (Mumby 2006). However, many stressors have been affecting this connectivity, including overexploitation, pollution, and even the removal of habitats (Grober-Dunsmore et al. 2009). This connectivity, especially in the coastal ecosystem, is important to the well functioning of environments, providing processes that maintain auto-regulation and resilience to impacts (Gillanders et al. 2003; McCook et al. 2009).

Reef fish may use non-reef habitats not only as nursery, but also for feeding and protection (Mumby et al. 2004; Dorenbosch et al. 2006). It is also widely recognized that

\footnotetext{
*Send correspondence to: Sergio Ricardo Floeter Laboratório de Biogeografia e Macroecologia Marinha, Universidade Federal de Santa Catarina - UFSC, CEP 88010-970, Florianópolis, SC, Brasil E-mail: sergiofloeter@gmail.com
}

the connection between shallow reefs and the open ocean is important for many fish species, especially carangids and sharks (e.g., Carcharhinus longimanus, a primarily oceanic species that uses reefs in specific phases or periods within the life cycle) (Carvalho-Filho 1999). The loss of non-reef habitats is one of the reasons attributed to the decline of fish species inhabiting reefs, even leading to local extinctions (Mumby et.al. 2004).

In Brazil, the diversity of organisms associated with reefs is imperiled by habitat-loss caused by pollution, overfishing and by-catch (Leão \& Dominguez 2000; Floeter et al. 2006). Although the Brazilian coast is vast, only a small fraction (1.57\%) is currently under protection (Brasil 2010). Moreover, these few protected areas are in many cases too distant (> $400 \mathrm{~km}$ ) from each other (Floeter et al. 2006), reducing their effectiveness due to low connectivity. Although reported worldwide (Cowen et al. 2002), the dynamics of inter-habitat connections is practically unknown along the Brazilian coast (Barletta et al. 2008). 
Here we aim to answer the following questions: 1) Which species among threatened reef fish and/or targeted species make use of non-reef habitats? 2) Which non-reef habitats should be prioritized in conservation efforts along the coast, and where?

\section{Methods}

\section{The database}

Reef fishes were defined as any shallow $(<100 \mathrm{~m})$ tropical/ subtropical benthic or benthopelagic fishes that constantly associate with hard substrates of coral, algal, or rocky reefs or that occupy adjacent sand substrate (i.e., use reef structures or the surrounding area for reproduction, feeding, and/ or protection purposes) (Floeter et al. 2008). Based on this definition, Carvalho-Filho \& Floeter (unpublished data) compiled a checklist of 559 reef fish species in
Brazilian waters. Species' distribution along 14 sites follows Floeter et al. (2008) and its references.

The reef sites evaluated along the Brazilian coast included (Figure 1; see Additional Supporting Information at www. abecol.org.br) biogenic reef areas: Manuel Luiz reefs, Rocas Atoll, Rio Grande do Norte, the coast stretching from Paraíba to Alagoas, North of Bahia, Abrolhos; and rocky reefs: Fernando de Noronha Archipelago, Saint Paul's Rocks, Espírito Santo, Trindade Island, Arraial do Cabo (the area encompassing Arraial do Cabo, Cabo Frio, Búzios and adjacent lagoons), Ilha Grande, São Paulo and Santa Catarina.

Species listed in our database were assigned to habitats they utilize during their life-cycles (using habitat [1] or not [0]), considering the natural distributions of such habitats found along the Brazilian coast and oceanic islands. Habitats were: biogenic reefs, rocky reefs, estuaries, mangroves, seagrass/algae beds, soft bottoms, the open ocean. Dataset

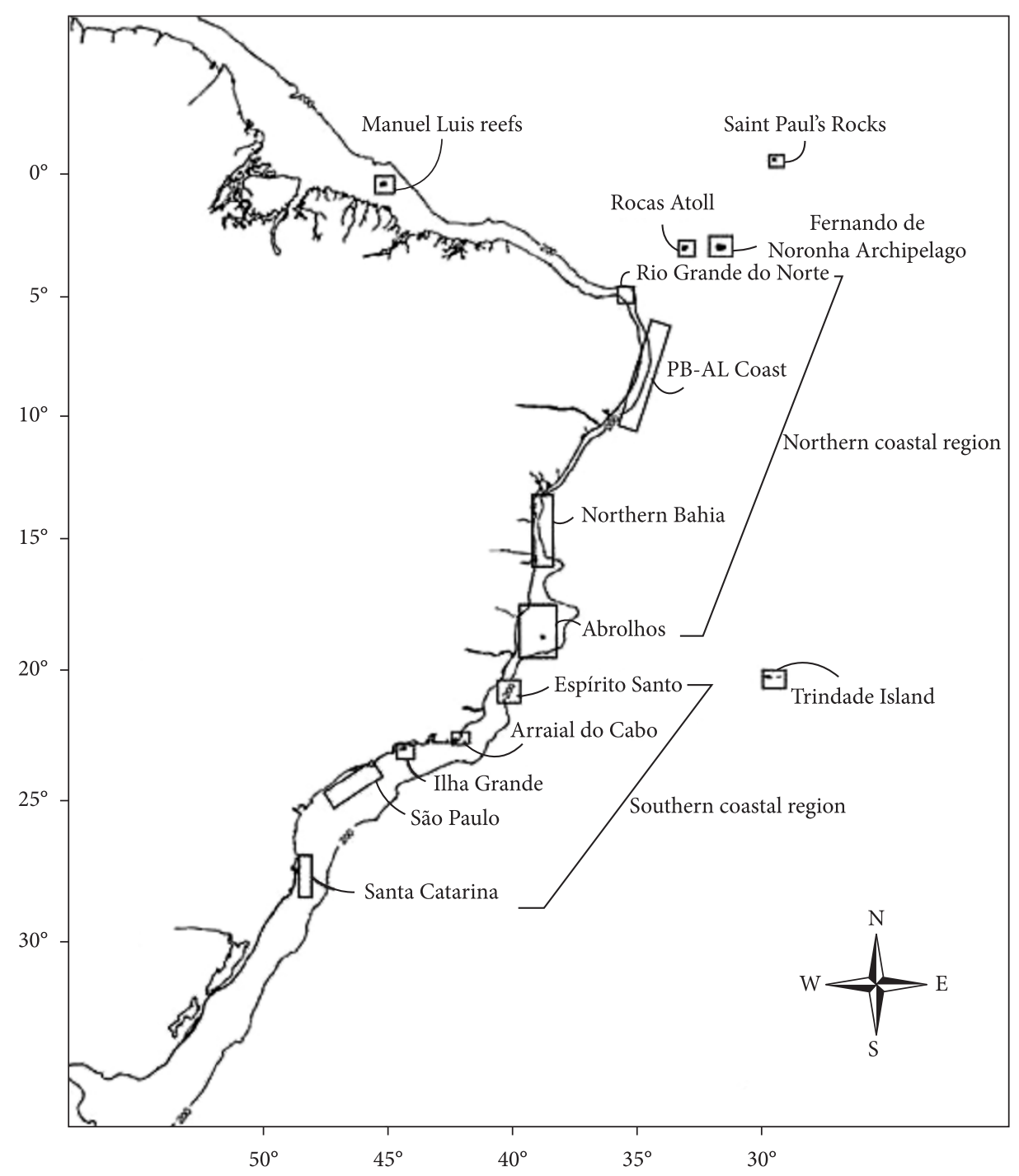

Figure 1. Map of the Brazilian coast showing all 14 reef sites used in this study. 
was assembled after extensive research in field guides, peer-reviewed papers, grey literature (i.e., $\mathrm{PhD}$ thesis), authors pers. obs., as well as from consultation of experts.

A recent publication evaluated the extent of protection for Brazilian rocky reefs, mangroves and estuaries (Brasil 2010). For this study, we listed the existing marine protected areas (MPAs) (including coastal protected areas with estuaries or mangroves within their boundaries) and habitats within their limits along the 14 reef sites. We also compiled data from other Brazilian official documents (Brasil 2006c, 2007, 2009a, 2009b).

\section{Threatened and/or targeted species}

In order to determine which Brazilian reef fish species are currently at risk of extinction, we compiled lists of threatened species at regional (state lists), national (Brasil 2004, 2005), and global levels (IUCN 2008). We considered the following IUCN threat categories: Critically endangered, Endangered and Vulnerable. We adopted the highest published threat category to which a species was assigned. The threat categories regarding Epinephelidae and Lutjanidae families came from a recent unpublished regional evaluation promoted by IUCN in Brazil (Tamandaré, PE, Brazil, December 9-10, 2008).

We also compiled data of targeted reef fish species (i.e. species exploited by fisheries) (Carvalho-Filho 1999; Floeter et al. 2006; Brasil 2006a,b; Froese \& Pauly 2010). For analysis purposes we only considered whether the species in question was targeted or not in our database (targeted [1] or not [0]).

\section{Data analysis}

In order to answer which species of threatened and/or targeted reef fish species make use of non-reef habitats, we used both the total number and the proportions of those species along the 14 reef sites. The proportions were transformed into arcsine and we performed a principal component analysis (PCA) to show what non-reef habitats possessed a greater proportion of such species for each region. Reefs were removed from this analysis in order to verify the influence of non-reef habitats on the distribution and composition of threatened/targeted species along the studied sites.

Our second question focused on which non-reef habitats should be prioritized in conservation efforts along the coast. We then performed binomial tests $(\alpha=5 \%)$ to investigate which habitats, in each of the 14 studied sites, had more targeted reef fish species. We tested if the proportion of targeted fish in each of the 14 sites, for each habitat considered, was greater than the overall proportion of targeted species found in the area studied. This analysis was also performed for threatened species.

\section{Results}

Thirty-six reef fish species ( $6 \%)$ fall under some sort of threat category in regional, national or global red lists. Among the threatened species, $75 \%(\mathrm{~N}=27)$ of them use non-reef habitats, such as mangroves, estuaries, and seagrass/algae beds (Table S1 in the Additional Supporting Information at www.abecol.org.br). Also, within threatened species, the families Epinephelidae (sensu Craig and Hastings 2007) and Lutjanidae are the most representative for Teleostei (eight and three species, respectively), while the families Carcharhinidae, Rhinobatidae and Sphyrnidae are the most representative for Elasmobranchii (two species each) (Table S1). Targeted species consisted of $42.7 \%(\mathrm{~N}=239)$ of all species, and $86.6 \%(\mathrm{~N}=207)$ of them are users of non-reef habitats. The families with a greater number of targeted species using non-reef habitats are Carangidae $(\mathrm{N}=30)$, and Carcharhinidae $(\mathrm{N}=11)$.

The Binomial test showed, with the exception of Saint Paul's Rocks, that the proportion of targeted reef fish that also use the open ocean is higher than the expected proportion at all sites $(p<0.05)$ (Figure 2$)$. In every coastal area, the highest proportion of targeted species was found on species that also use estuaries. There is also a high proportion of these species using mangroves in the coast from Paraíba to Alagoas (PB-AL), north of Bahia and Arraial do Cabo (Figure 2). Binomial tests performed for threatened species revealed no significant difference between sites, with the exception of the proportion of threatened species in Rio Grande do Norte (RN) that use estuaries, and those utilizing the open ocean in Rocas Atoll.

The highest percentage of targeted species for all its non-reef habitats was found in RN (from 51 to $90 \%$ of all species/ habitat) (Figure 2). São Paulo and the PB-AL coast had the highest number of targeted species using non-reef habitats (Table 1). Estuaries presented the highest number of both threatened $(\mathrm{N}=14)$ and targeted $(\mathrm{N}=114)$ species (Table 1). The sites exhibiting the highest number of threatened and targeted species for each habitat type are described in Table 1.

The principal component analysis (PCA) for threatened species (Figure 3 ) highlighted the importance of seagrass/ algae beds to threatened species of the Northeastern reef areas (from RN to Abrolhos), Espírito Santo and Arraial do Cabo, while the oceanic islands and Manuel Luiz reefs were more related to open ocean environments. Estuaries and mangroves are important to threatened reef fish along the entire coastal area. In São Paulo, we found the highest number of threatened species $(\mathrm{N}=29)$, while Santa Catarina contained the greatest proportion of threatened species (8.2\% of the total) (Figure 3 ). The PCA for targeted reef fish showed a greater proportion of species using mangroves, estuaries and seagrass/algae beds in the Northeast, Espírito Santo and Arraial do Cabo regions; the Southeast-South area showed a higher proportion of oceanic and soft bottom-associated species (Figure S1 in the Additional Supporting Information at www.abecol.org.br). The area 

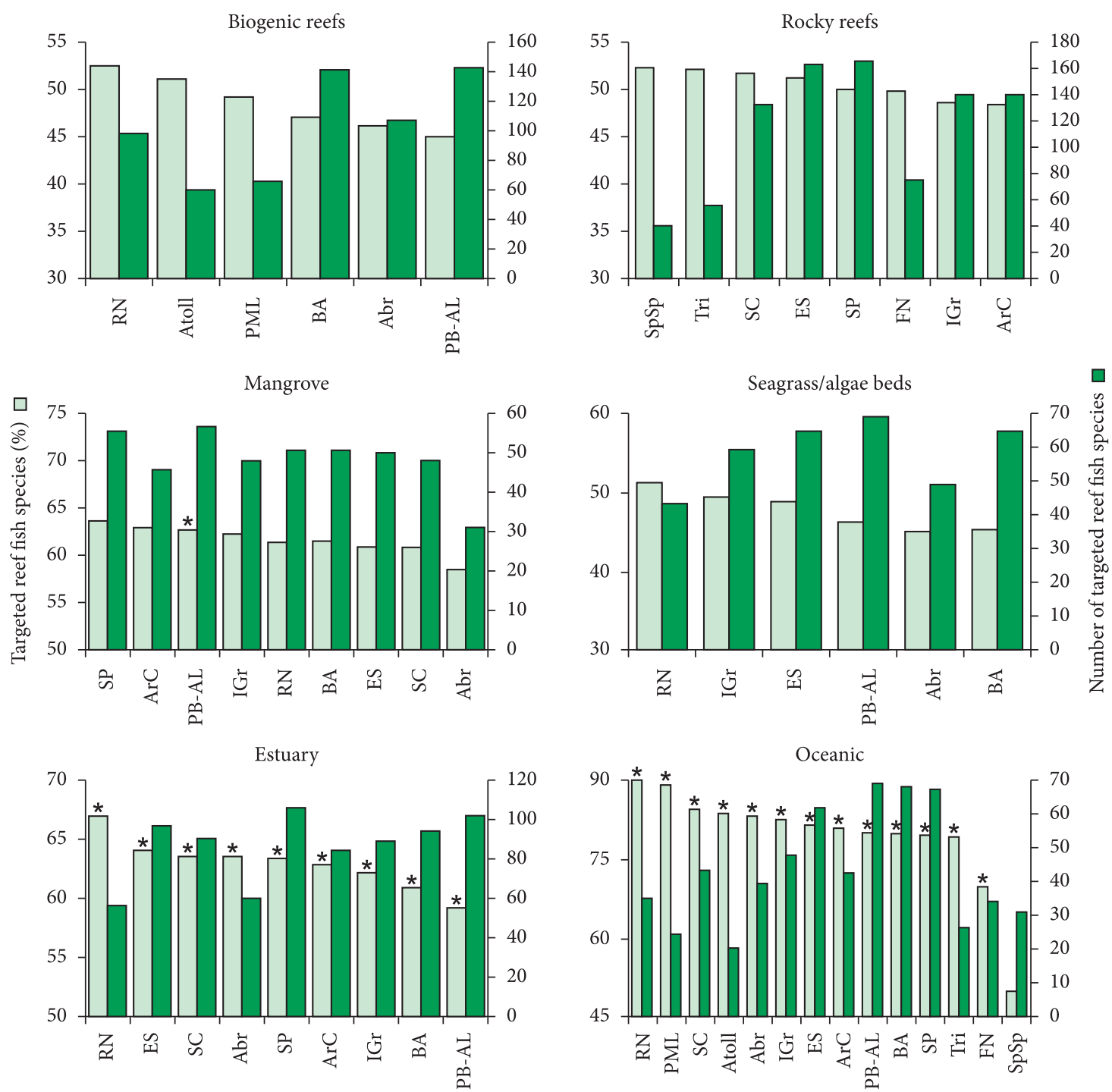

Figure 2. Distribution of targeted reef fish species according to their habitat-use. ${ }^{*}=$ binomial test was significant $(\mathrm{p}<0.05)$ between the proportion of targeted species in each one of the sites, for each habitat, and the expected proportion of species for each site. Sites abbreviations: $\mathrm{PML}=$ Manuel Luiz Reefs, Atoll $=$ Rocas Atoll, $\mathrm{SpSp}=$ Saint Paul's Rocks, FN = Fernando de Noronha Archipelago, Tri $=$ Trindade Island, $\mathrm{RN}=$ Rio Grande do Norte, $\mathrm{PB}-\mathrm{AL}=$ the coast from Paraíba to Alagoas, $\mathrm{BA}=$ North of Bahia, $\mathrm{Abr}=\mathrm{Abrolhos}$ area, ES = Espírito Santo, ArC = Arraial do Cabo/Cabo Frio, IGr = Ilha Grande, SP = São Paulo, SC = Santa Catarina.

along the PB-AL coast presented the highest number of targeted species $(\mathrm{N}=212)$ and Saint Paul's Rocks had the highest proportion of targeted species (57\%).

Every reef site studied had at least one MPAs within their limits (Table 1). Additionally, reefs and non-reef habitats along the 14 reef sites used were located within at least one protected area. However, most MPAs in Brazil are of sustainable use ( 47 versus 32 no-take MPAs), i.e., where fishing is allowed under some type of regulation. Moreover, Saint Paul's Rocks, RN, the north coast of Bahia and Arraial do Cabo do not have any strict no-take areas within their boundaries (Table 1).

Two recent works by the Brazilian Ministry of the Environment (Brasil 2007, 2010) have mapped reefs, mangroves and estuaries along the coast, and determined the amount of protection for these habitats. Although the data reported for each work is not entirely comparable, they still represent the most complete publications regarding marine conservation in Brazil. Data from the Coral Atlas (Brasil 2007), are based entirely on conservation units while the other publication (2010) considers data from each coastal state. According to the Coral Atlas (Brasil 2007), biogenic reefs have a relatively high percentage (44.3-100\%) of protection inside MPAs. The important exception is northern Bahia, where there is no protected area (Brasil 2007).

Brazilian rocky reefs have a medium-high protection level (29-86.9\%) which extends from Espírito Santo to Santa 


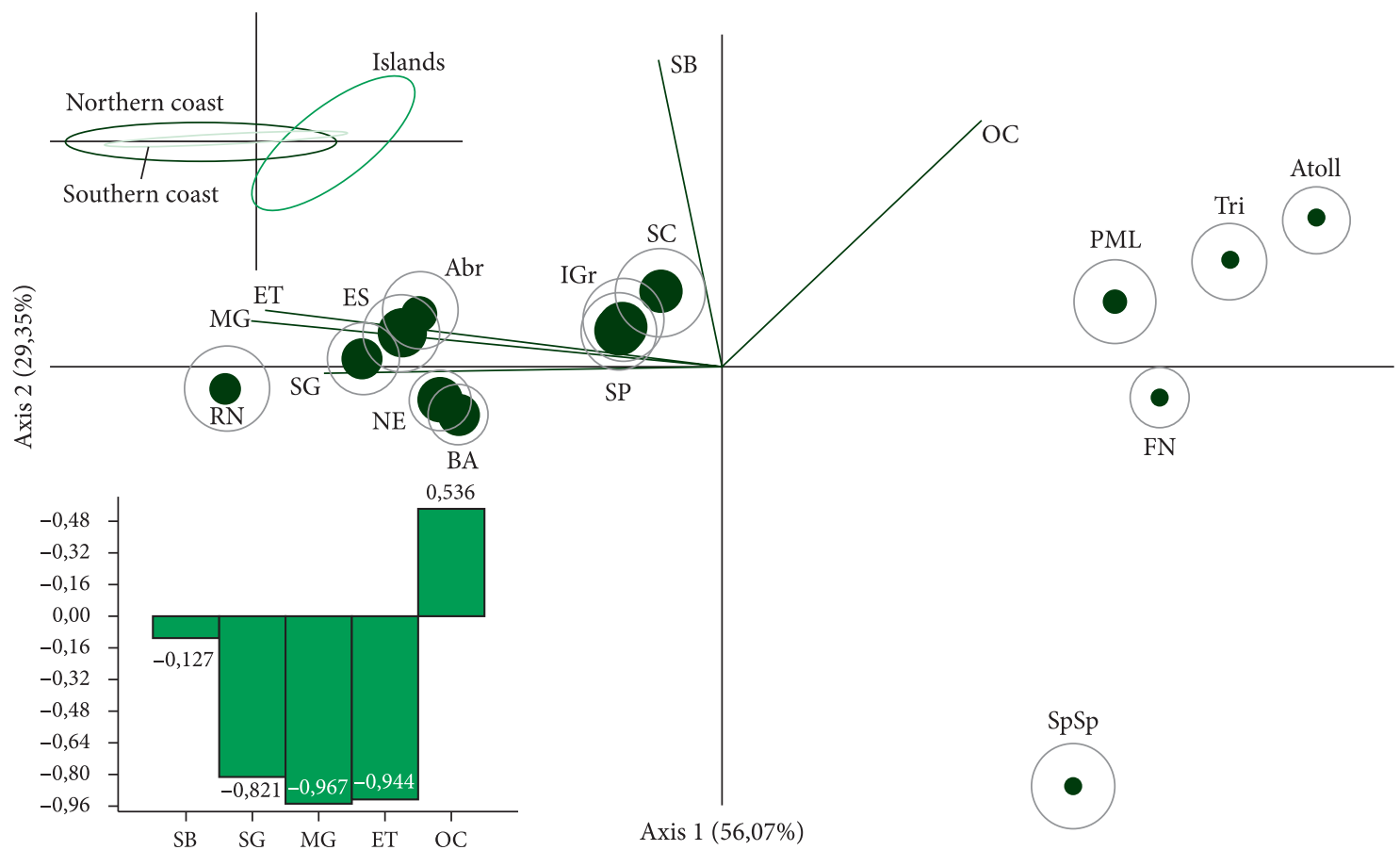

Figure 3. PCA showing the proportion of threatened reef fish species in each one of the 14 sites. Solid spheres are proportional to the number of threatened species in each site (Maximum in SP $=29$ threatened species). Grey circles are proportional to the percentage of threatened species in each site (Maximum in SC $=8.2 \%$ of threatened species). The ellipses on the smaller PCA show the $95 \%$ confidence for each group. Graph refers to correlation loadings. Sites abbreviations: PML $=$ Manuel Luiz Reefs, Atoll $=$ Rocas Atoll, $\mathrm{SpSp}=$ Saint Paul's Rocks, FN = Fernando de Noronha Archipelago, Tri $=$ Trindade Island, $\mathrm{RN}=$ Rio Grande do Norte, $\mathrm{PB}-\mathrm{AL}=$ the coast from Paraíba to Alagoas, $\mathrm{BA}=$ North of Bahia, Abr = Abrolhos area, ES = Espírito Santo, ArC = Arraial do Cabo, IGr $=$ Ilha Grande, SP = São Paulo, SC = Santa Catarina. Habitats abbreviations: SG = seagrass/algae beds, $\mathrm{SB}=$ soft bottoms, $\mathrm{MG}=\mathrm{mangroves}$, $\mathrm{ET}=$ estuaries, $\mathrm{OC}=$ open ocean.

Catarina (Brasil 2010). São Paulo has the highest protection level for these habitats (86.9\%), being the majority marine reserves (no-take zones). Mangroves have a very different level of protection along the Brazilian coastline, ranging from $13.5 \%$ in Santa Catarina (mostly reserves) to $78.7 \%$ in Bahia (mostly Environmental Protected Areas - EPA, for sustainable use). There are no reserves protecting such habitats in Rio Grande do Norte or in Alagoas (Brasil 2010). Estuaries protection ranges from 1.1\% in Santa Catarina to $69.5 \%$ (mostly EPAs) in São Paulo. There are no marine reserves protecting such habitat from Rio Grande do Norte to Alagoas (Brasil 2010).

\section{Discussion}

Our results present for the first time a complete set of information regarding the use of non-reef habitats for both threatened and targeted reef fish species in Brazil. Epinephelidae, Lutjanidae, Carangidae, Carcharhinidae, Rhinobatidae and Sphyrnidae are the families with the majority of species in these categories. Protecting the connectivity between reefs and non-reef habitats that are used by these species would help both individual's development and population maintenance by including all critical life-stages under some type of protection (e.g., Mumby et al. 2004).
Estuaries hold the greatest number of both threatened and targeted reef fish species that use non-reef habitats (Figure 2, Table 1) in Brazil. At the same time, estuaries have the lowest protection and the least amount of reserves compared to other mapped habitats along the Brazilian coast (Brasil 2010). We reinforce the urgent need of creating ecological corridors (including no-take zones) among reefs and other habitats, since negative impacts in the course of an organism early life stages could indirectly affect the abundance of adult specimens (Sale et al. 2010).

São Paulo's coast present the greatest number of threatened reef fish species that also use non-reef habitats (Table 1). In 2008, São Paulo's government established a network of MPAs that encompasses all federal, state, and municipalitymanaged MPAs. Such networks aim to set strategies for both conservation and development activities in coastal and marine zones. However, little can be achieved if such MPAs are not meeting the conservation goals established for each type of protected areas.

The highest number of targeted reef fish that use non-reef habitats is in PB-AL coast, where artisanal fishing is the most common type of harvesting (Diegues 2008). Some targeted reef fish species have been monitored by the project REVIZEE, and management suggestions have been made for these species (Brasil 2006a, b). However, single-species 


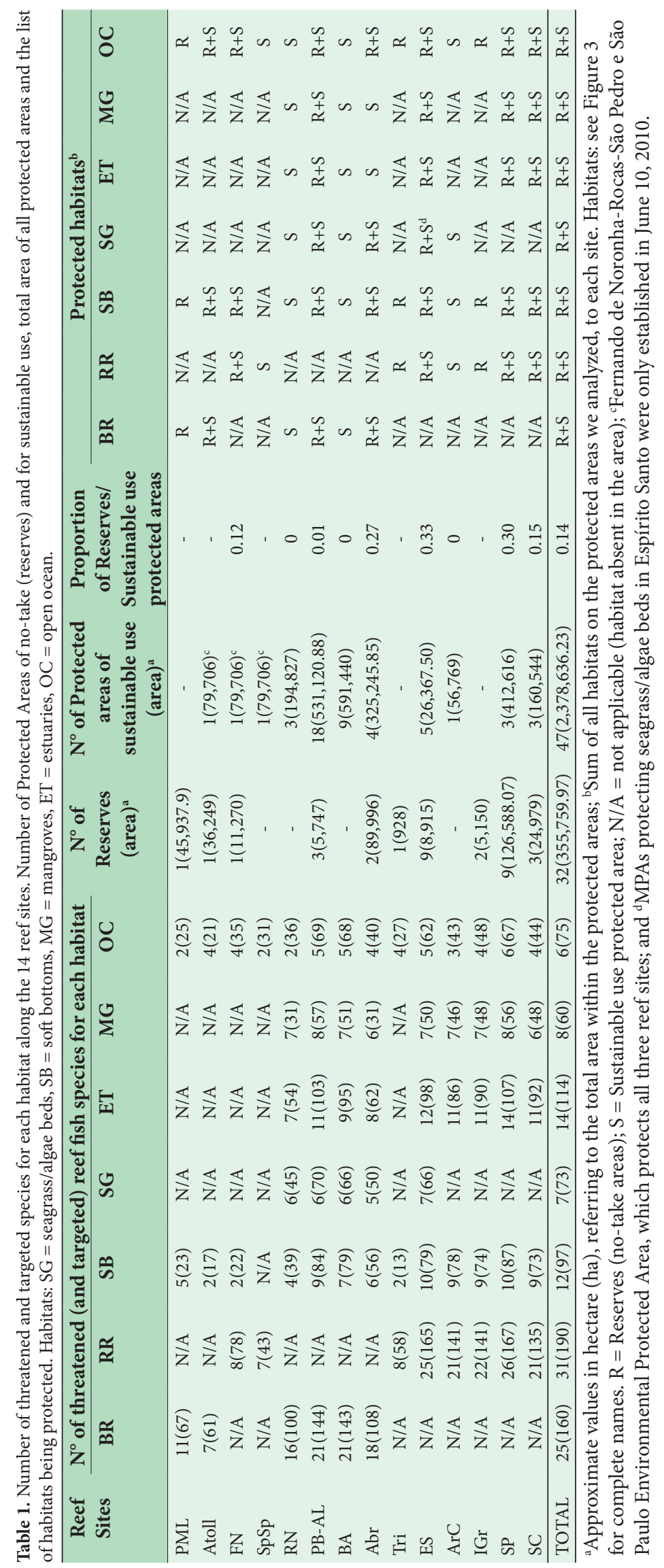


management plans often do not work when we have to consider complex habitat networks (Freire 2005).

Every site used in our study has protected areas, however, mostly for sustainable use (Table 1). Due to the lack of planning and enforcement, it is easy to find many illegal activities within these areas (Sá \& Ferreira 1999). For example, several shrimp farms can be found within many EPAs in the Northeast, frequently making them appear as 'paper parks' (Boeckmann \& Geber 2006; Gerhardinger et al. 2010). In addition, it is easier to enforce a fully protected marine reserve (no-take zone) than 'partially' protected areas, the latter being sometimes no better than areas without regulations. The 'virtual status' of a protected area is of great concern when a mapping approach (such as in Brasil 2007, 2010) is used regardless of the actual status of the enforcement of the protected area analyzed (if each MPA is really functional or not).

Additionally, the protected areas mentioned in Table 1 in many cases do not correspond to marine areas, also including coastal land areas. A very detailed mapping of MPAs, describing which and how much of habitats are actually being protected, the types of human influences surrounding them, as well as the real functional status of each MPA, would enable better decisions on the creation of coastal and marine ecological corridors in Brazil. Only a few works have been produced in the past years regarding this subject (Brasil 2006c, 2009b, 2010), but there is still information missing, especially on habitat-specific status. Also, there are no Brazilian-wide studies concerning the conservation of other habitats, such as seagrass/algae beds, soft bottoms and the open ocean. Such initiative would provide essential information that could be used to point continuous areas which would better represent and protect these important resources.

\section{Acknowledgements}

We thank Dr. Maurício Moura for helping on the data analysis, Dr. Luis Fernando Fávaro for helping with estuarine species. Rachel Labbe-Bellas for helping on the English version of the manuscript and anonymous reviewers that helped improving previous versions of this manuscript. DAVN thanks CAPES for finnancial support.

\section{References}

Barletta $\mathrm{M}$ et al. 2008. Factors affecting seasonal variations in demersal fish assemblages at an ecocline in a tropicalsubtropical estuary. Journal of Fish Biology, 73:1314-1336. http://dx.doi.org/10.1111/j.1095-8649.2008.02005.x

Boeckmann CE \& Geber FO, 2006. Propostas para o desenvolvimento sustentável do setor pesqueiro no estado de Pernambuco, com apoio de incentivos fiscais. Boletim do Instituto de Pesca, 32(2):199-211.

Brasil. Ministério do Meio Ambiente - MMA, 2004. Instrução Normativa $n^{\circ}$ 5, de 21 de Maio de 2004. Lista nacional das espécies de invertebrados aquáticos e peixes ameaçadas de extinção. Diário Oficial da República Federativa do Brasil, Brasília (2004 jan. 28).

Brasil. Ministério do Meio Ambiente - MMA, 2005. Instrução Normativa $\mathrm{n}^{\circ} 52$, de 8 de novembro de 2005. Alteração da Instrução Normativa $n^{\circ}$ 5, de maio de 2004. Diário Oficial da República Federativa do Brasil, Brasília (2005 out. 09).

Brasil. Ministério do Meio Ambiente - MMA, 2006a. Programa REVIZEE: avaliação do potencial sustentável de recursos vivos na zona econômica exclusiva: relatório executivo. Brasília.

Brasil. Ministério do Meio Ambiente - MMA, 2006b. Análise das principais pescarias comerciais da região Sudeste-Sul do Brasil: dinâmica populacional das espécies em explotação II. Brasília.

Brasil. Ministério do Meio Ambiente - MMA, 2006c. Atlas dos recifes de coral nas unidades de conservação brasileiras. Brasília.

Brasil. Ministério do Meio Ambiente - MMA, 2007. Áreas prioritárias para conservação, uso sustentável e repartição dos benefícios da biodiversidade brasileira - zona marinha. Brasília.

Brasil. Ministério do Meio Ambiente - MMA, 2009a. Corredores ecológicos - Implementação da porção marinha do Corredor Central da Mata Atlântica. Brasília.

Brasil. Ministério do Meio Ambiente - MMA, 2009b. Macrodiagnóstico da Zona Costeira e Marinha do Brasil. Brasília.

Brasil. Ministério do Meio Ambiente - MMA, 2010. Panorama da conservação dos ecossistemas costeiros e marinhos no Brasil. Brasília.

Carvalho-Filho A, 1999. Peixes da costa brasileira. Ed. Marca D’água.

Cowen RK et al., 2002. Population connectivity in marine systems. Report of a workshop to develop science recommendations for the National Science Foundation.

Craig MT \& Hastings PA, 2007. A molecular phylogeny of the groupers of the subfamily Epinephelinae (Serranidae) with a revised classification of the Epinephelini. Ichthyological Research, 54:1-17. http://dx.doi.org/10.1007/ s10228-006-0367-x

Diegues ACS. 2008. Marine protected areas and artisanal fisheries in Brazil. Chennai, India: International Collective in Support of Fishworkers.

Dorenbosch M et al., 2006. Seagrass beds and mangroves as potential nurseries for the threatened Indo-Pacific humphead wrasse, Cheilinus undulates and Caribbean rainbow parrotfish, Scarus guacamaia. Biological Conservation, 129:277-282. http://dx.doi.org/10.1016/j.biocon.2005.10.032

Floeter SR et al., 2006. Effects of fishing and protection on Brazilian reef fishes. Biological Conservation, 128:391-402. http://dx.doi.org/10.1016/j.biocon.2005.10.005

Floeter SR et al., 2008. Atlantic reef fish biogeography and evolution. Journal of Biogeography, 35:22-47.

Freire KMF, 2005. Fishing impacts on marine ecosystems off Brazil, with emphasis on the Northeastern region. [PhD Thesis]. University of British Columbia. 
Froese R \& Pauly D. 2010. Fishbase. Available from: <www. fishbase.org $>$.

Gerhardinger LC et al., 2010. Marine protected dramas: the flaws of the Brazilian national system of marine protected areas. Environmental Management, 47(4):630-43. PMid:20865415. http://dx.doi.org/10.1007/s00267-010-9554-7

Gillanders BM et al., 2003. Evidence of connectivity between juvenile and adult habitats for mobile marine fauna: an important component of nurseries. Marine Ecology Progress Series, 247:281-295. http://dx.doi.org/10.3354/meps247281

Grober-Dunsmore et al., 2009. A landscape ecology approach for the study of ecological connectivity across tropical marine seascapes In: Nagelkerken I (ed.). Ecological connectivity among tropical coastal ecosystems. Springer. p. 493-530. http://dx.doi.org/10.1007/978-90-481-2406-0_14

International Union for Conservation of Nature - IUCN, 2008. The IUCN red list of threatened species. Available from: <http://www.iucnredlist.org >.
Leão ZMAN \& Dominguez JM, 2000. Tropical coast of Brazil. Marine Pollution Bulletin, 41:112-122. http://dx.doi. org/10.1016/S0025-326X(00)00105-3

McCook LJ et al., 2009. Management under uncertainty: guidelines for incorporating connectivity into the protection of coral reefs. Coral Reefs, 28:353-366. http://dx.doi.org/10.1007/ s00338-008-0463-7

Mumby PJ et al. 2004. Mangroves enhance the biomass of coral reef fish communities in the Caribbean. Nature 427: 533-536. PMid:14765193. http://dx.doi.org/10.1038/nature02286

Mumby PJ, 2006. Connectivity of reef fish between mangroves and coral reefs: algorithms for the design of marine reserves at seascape scales. Biological Conservation, 128:215-222. http://dx.doi.org/10.1016/j.biocon.2005.09.042

Sá RML \& Ferreira L, 1999. Áreas protegidas ou espaços ameaçados: o grau de implementação e a vulnerabilidade das Unidades de Conservação federais brasileiras de uso indireto. Brasília: WWF Brasil. Technical report.

Sale PF et al., 2010. Preserving reef connectivity: a handbook for marine protected area managers.

Received: May 2011

First Decision: May 2011

Accepted: June 2011 